
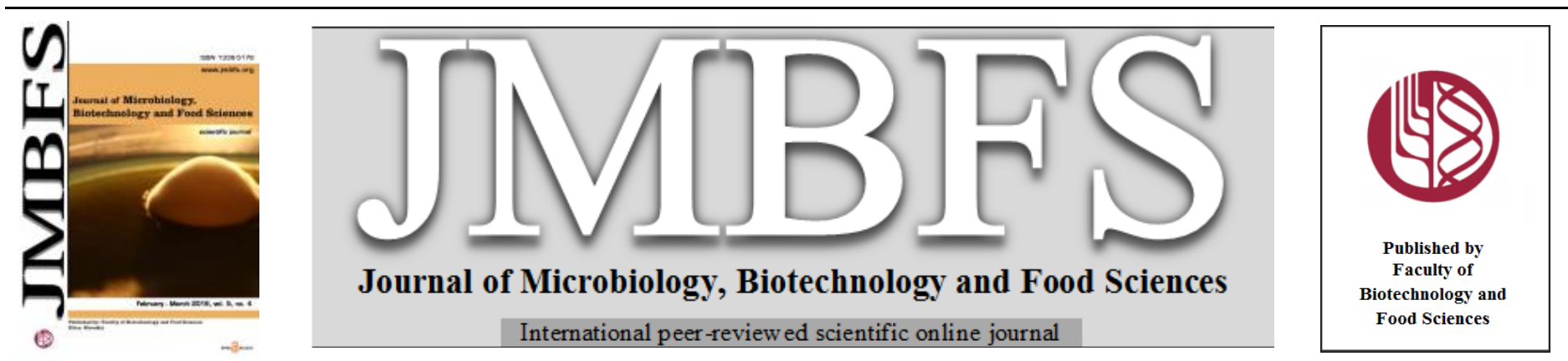

\title{
SOUND STIMULATION CAN INFLUENCE MICROBIAL GROWTH AND PRODUCTION OF CERTAIN KEY METABOLITES
}

\author{
Abheelasha Shah, Akansha Raval, Vijay Kothari*
}

\section{Address(es):}

Institute of Science, Nirma University, Ahmedabad, India.

*Corresponding author: vijay.kothari@nirmauni.ac.in; vijay23112004@yahoo.co.in

doi: 10.15414/jmbfs.2016.5.4.330-334

\section{ARTICLE INFO}

Received 25. 6. 2015

Revised 23. 10. 2015

Accepted 5. 11. 2015

Published 1. 2. 2016

\section{Regular article}

open $O$ access

\begin{abstract}
Effect of two different audible sound (music) patterns on six different microorganisms was investigated. Both the sound patterns namely Ahir Bhairav $(172-581 \mathrm{~Hz})$ and Piloo $(86-839 \mathrm{~Hz})$ were able to significantly affect microbial growth and production of certain key metabolites by the test microbes. Faster uptake of glucose from the growth medium by Brevibacillus parabrevis and Saccharomyces cerevisiae was observed under the influence of sound. Production of quorum sensing-regulated pigments, prodigiosin and violacein, respectively by Serratia marcescens and Chromobacterium violaceum was also notably affected by sound treatment. Further investigation to decipher molecular basis of microbial response to sound is warranted to understand the mechanism how audible sound interacts with microbial cells, and how the microbial population(s) modulate their behavior in response to sound stimulation.
\end{abstract}

Keywords: Sound stimulation, Music, Growth, Pigment, Membrane, Quorum sensing

\section{INTRODUCTION}

Living cells and organisms can sense changes in various environmental factors in their surroundings, and respond accordingly. Effect of many of the environmental factors such as $\mathrm{pH}$, temperature, osmotic pressure, light, etc. has been well characterized. However sound remains one such factor, which despite being widely present in the growth environment of almost all living systems, whose effect on living cells/organisms has not been characterized that well. Sound's effect on higher organisms having some sort of sound-sensing organ (e.g., ears in animals) is of obvious nature. There have been few reports (Hassanien et al., 2014) describing the effect of noise and/or music on plants and animals. Not many such systematic investigations describing influence of sound on microorganisms are available. Much remains to be investigated on how microorganisms interact with external sound, and how they behave when placed in an external sound field. This is a relatively nascent area of scientific research. Certain earlier reports (Matsuhashi et al., 1998) have indicated microorganism's ability to produce, sense, and respond to sound. However most reports are concerning the sound beyond human audible range i.e. 20-20,000 Hz. In the present work, we have focused on the effect of audible sound (composed of multiple frequencies) on selected microorganisms, when the sound is provided in form of a particular pattern i.e. music.

\section{MATERIALS AND METHODS}

\section{Test organisms}

List of the prokaryotic and eukaryotic microorganisms employed in this study, and the parameter(s) on which the influence of sound was investigated, is provided in Table 1. All the test strains were procured from Microbial Type Culture Collection (MTCC), Chandigarh. All media/media components were from HiMedia, Mumbai.

Table 1 Test organisms

\begin{tabular}{|c|c|c|c|c|c|c|}
\hline No. & Organism & $\begin{array}{l}\text { MTCC } \\
\text { code }\end{array}$ & Growth Medium & $\begin{array}{c}\text { Incubation } \\
\text { temperature } \\
\left({ }^{\circ} \mathrm{C}\right)\end{array}$ & $\begin{array}{l}\text { Incubation time } \\
\text { (h) }\end{array}$ & Parameter(s) tested \\
\hline 1. & Chromobacterium violaceum & 2656 & Nutrient broth & 35 & 48 (under static & $\begin{array}{l}\text { Growth and violacein } \\
\text { production }\end{array}$ \\
\hline 2. & Serratia marcescens & 97 & Nutrient broth & 28 & condition) & $\begin{array}{l}\text { Growth and } \\
\text { prodigiosin production }\end{array}$ \\
\hline 3. & Xanthomonas campestris & 2286 & $\begin{array}{l}\text { Tryptone yeast extract broth } \\
\text { (supplemented with } \mathrm{CaCl}_{2} \text { ) }\end{array}$ & $\begin{array}{l}\text { Room } \\
\text { temperature }\end{array}$ & $\begin{array}{l}72 \text { (with intermittent } \\
\text { shaking) }\end{array}$ & $\begin{array}{l}\text { Growth and } \\
\text { exopolysaccharide } \\
\text { (EPS) production }\end{array}$ \\
\hline 4. & Brevibacillus parabrevis & 2708 & $\begin{array}{l}\text { Broth containing } \\
\mathrm{CMC}^{-\mathrm{Na}^{\#}}\end{array}$ & 35 & $\begin{array}{l}72 \text { (with intermittent } \\
\text { shaking) }\end{array}$ & $\begin{array}{c}\text { Growth and cellulase } \\
\text { activity }\end{array}$ \\
\hline 5. & Lactobacillus Plantarum & 2621 & MRS broth & $\begin{array}{c}\text { Room } \\
\text { temperature }\end{array}$ & $\begin{array}{l}48 \text { (under static } \\
\text { condition) }\end{array}$ & Growth and $\mathrm{pH}$ \\
\hline 6. & Saccharomyces cerevisiae & 170 & Glucose yeast extract broth & $\begin{array}{c}\text { Room } \\
\text { temperature }\end{array}$ & 48 (static) & $\begin{array}{l}\text { Growth and alcohol } \\
\text { production }\end{array}$ \\
\hline
\end{tabular}




\section{Sound treatment}

Sound stimulation of the test cultures was executed as described in our previous study (Sarvaiya and Kothari, 2015). Inoculum of test organism from it activated culture was prepared in sterile normal saline and was standardized to 0.5 McFarland turbidity standard. The tubes with growth medium after inoculation were put into a glass chamber (Merck; $225 \times 225 \times 125 \mathrm{~cm}$ ). A speaker was placed in this glass chamber at a distance of $15 \mathrm{~cm}$ from the inoculated test tubes/flasks, from which the sound was delivered (sound delivery was provided throughout the period of incubation). This glass chamber was covered with a glass lid, and multiple layers of cloth and paper were used to cover the lid. This was done to prevent any possible leakage of sound from the chamber, and also to avoid any possible interference from external sound. Similar chamber was used to house the control (not stimulated with music) group test tubes. One speaker was also placed in the glass chamber used for the control test tubes at a distance of $15 \mathrm{~cm}$, where no electricity was supplied and no sound was generated. Frequency of the test sound was analyzed by NCH WavePad Sound Editor Masters Edition v. 5.5. Of the two music types used, raag Ahir Bhairav (sound-I) was found to be composed of sound falling in the frequency range 150$7811 \mathrm{~Hz}$, of which the range $172-581 \mathrm{~Hz}$ was dominant (Figure 1). Similarly, frequency range of the second test music raag Piloo (Teentaal; sound-II) was determined to be $43-5620 \mathrm{~Hz}$, of which the range $86-839 \mathrm{~Hz}$ was dominan (Figure 2). Source for both these sound patterns was the commercially available musical disc titled Call of the Valley (Saregama India Ltd., Kolkata). Intensity of the sound, measured with a sound level meter (acd machine control Ltd.) at a distance of $15 \mathrm{~cm}$ from the speaker was 70-90 dB (in case of Ahir Bhairav), and 85-110 dB (in case of Piloo). Absence of detectable sound in the control chamber was ensured using decibel meter.

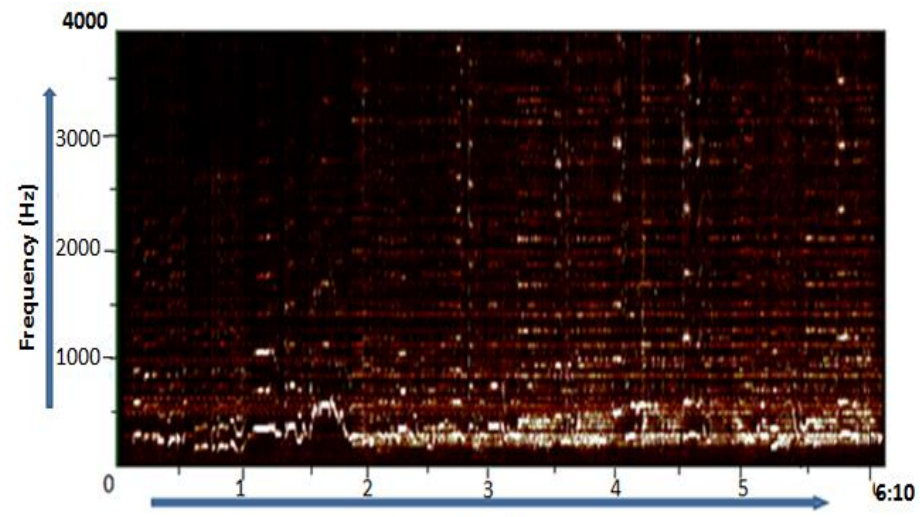

Time (min.)

Figure 1 Frequency distribution over time for the raag Ahir Bhairav

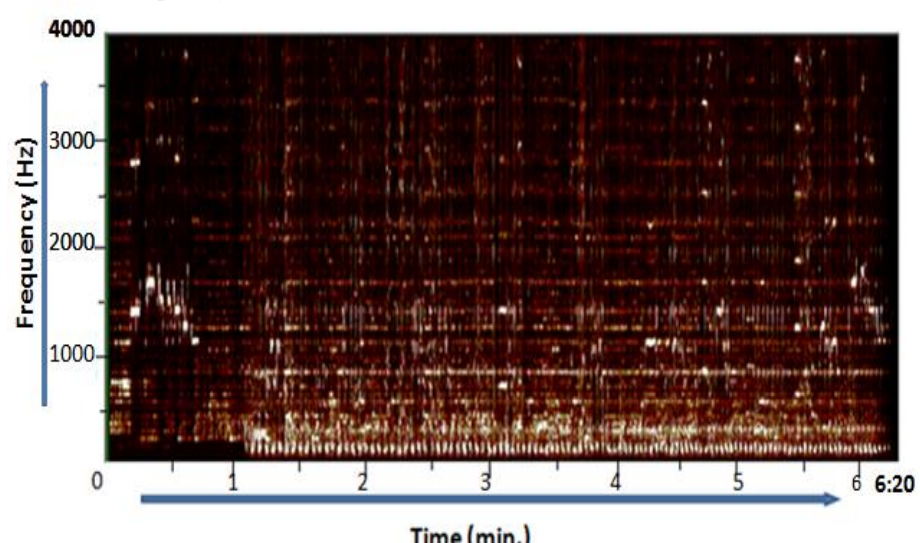

Figure 2 Frequency distribution over time for the raag Piloo (Teentaal)

Violacein extraction and estimation

After measuring growth by recording OD at $660 \mathrm{~nm}$ using spectrophotometer (Agilent- Carry 60), violacein extraction (Choo et al., 2006) was done from $C$. violaceum culture. Briefly, $3 \mathrm{~mL}$ of the culture broth was centrifuged (REMI CPR-24 Plus) at $12,000 \mathrm{rpm}(13,520 \mathrm{~g})$ for 15 minute at $25^{\circ} \mathrm{C}$, and the resulting supernatant was discarded. The remaining cell pellet was resuspended into $3 \mathrm{~mL}$ of DMSO purchased from Merck (Mumbai), and incubated at room temperature for $30 \mathrm{~min}$, followed by centrifugation at $12,000 \mathrm{rpm}$ for $15 \mathrm{~min}$. The violacein extracted in the supernatant was estimated by measuring OD at $585 \mathrm{~nm}$.

\section{Prodigiosin extraction and estimation}

After quantifying growth at $660 \mathrm{~nm}$, prodigiosin extraction was carried out from S. marcescens culture as described by Pradeep et al. (2013). Briefly, $3 \mathrm{~mL}$ of the culture broth was centrifuged at $12,000 \mathrm{rpm}$ for $15 \mathrm{~min}$, and the resulting supernatant was discarded. The remaining cell pellet was resuspended in $3 \mathrm{~mL}$ of acidified methanol ( $4 \mathrm{~mL}$ of $\mathrm{HCl}$ into $96 \mathrm{~mL}$ of methanol; Merck), followed by incubation in dark at room temperature for $30 \mathrm{~min}$. This was followed by centrifugation at $12,000 \mathrm{rpm}$ for $15 \mathrm{~min}$ at $4^{\circ} \mathrm{C}$. Prodigiosin in the resulting supernatant was estimated by measuring OD at $535 \mathrm{~nm}$.

\section{Alcohol estimation}

Alcohol was estimated photometrically. S. cerevisiae culture broth was centrifuged at 12,000 rpm for $15 \mathrm{~min}$, and the supernatant was used for alcohol estimation (Williams \& Darwin, 1950). $1 \mathrm{~mL}$ of the supernatant was mixed with $15 \mathrm{~mL}$ of distilled water, and $25 \mathrm{~mL}$ of potassium dichromate reagent, followed by $10 \mathrm{~mL}$ of additional distilled water. Then incubation was carried out in water bath at $60^{\circ} \mathrm{C}$ for $30 \mathrm{~min}$, followed by measurement of OD at $600 \mathrm{~nm}$. Standard curve was prepared using absolute ethanol procured from Eureka, Ahmedabad at $2-10 \% \mathrm{v} / \mathrm{v}$.

\section{EPS quantification}

Following estimation of growth by measuring OD at $660 \mathrm{~nm}$, culture broth was subjected to centrifugation at 7,500 rpm $(6,600 \mathrm{~g})$ for $15 \mathrm{~min}$, and the cell free supernatant (CFS) was used for EPS quantification using the method described in Li et al., (2012) with some modification. Briefly, $40 \mathrm{~mL}$ of chilled acetone (Merck) was added to $20 \mathrm{~mL}$ of CFS, and allowed to stand for $30 \mathrm{~min}$. The EPS precipitated thus was separated by filtration through pre-weighed Whatman \# 1 filter paper (Whatman International Ltd., England). Filter paper was dried at $60^{\circ} \mathrm{C}$ for $24 \mathrm{~h}$, and weight of EPS on paper was calculated.

Glucose uptake assay

Concentration of glucose present in the medium (after inoculation of test organism) was estimated at different time intervals, employing the photometric method using dinitrosalicylic acid (DNSA) (Nigam and Ayyagari, 2008). For this experiment Brevibacillus parabrevis was inoculated into a growth medium containing $0.5 \mathrm{~g} / \mathrm{L}$ glucose, $0.5 \mathrm{~g} / \mathrm{L} \mathrm{NaCl}, 0.5 \mathrm{~g} / \mathrm{L}$ beef extract, $0.5 \mathrm{~g} / \mathrm{L}$ yeast extract, and $0.5 \mathrm{~g} / \mathrm{L}$ peptone. Medium for $S$. cerevisiae contained $10 \mathrm{~g} / \mathrm{L}$ glucose, $5 \mathrm{~g} / \mathrm{L}$ yeast extract and $10 \mathrm{~g} / \mathrm{L}$ peptone.

Estimation of cellulase activity

B. parabrevis was grown in a CMC supplemented broth $(0.5 \mathrm{~g} / \mathrm{L}$ peptone, $0.5 \mathrm{~g} / \mathrm{L}$ $\mathrm{NaCl}, 0.5 \mathrm{~g} / \mathrm{L}$ Beef extract, $0.5 \mathrm{~g} / \mathrm{L}$ Yeast extract, $20 \mathrm{~g} / \mathrm{L} \mathrm{CMC}-\mathrm{Na})$. The cell free supernatant obtained from $B$. parabrevis culture after centrifugation of the culture broth $(10,000 \mathrm{rpm} ; 9,390 \mathrm{~g})$ was used as crude cellulase preparation. $0.5 \mathrm{~mL}$ of the supernatant was mixed with $0.5 \mathrm{~mL}$ of $1 \%$ carboxymethyl cellulose (CMC $\mathrm{Na}$ salt; Merck), followed by incubation at $50^{\circ} \mathrm{C}$ for $30 \mathrm{~min}$. The amount of glucose released as a result of cellulase activity was quantified using DNSA colorimetric assay. The international unit (IU) of the cellulase was calculated as: $\mathrm{IU}=[(\mu \mathrm{g}$ of glucose $) / 180$ (molecular weight of glucose) $\mathrm{x} 30$ (incubation time) $\mathrm{x}$ 0.5 (aliquote)] (Nigam and Ayyagari, 2008).

\section{Statistical analysis}

All the experiments were performed in triplicate, and measurements are reported as mean \pm standard deviation (SD). Statistical significance of the data was evaluated by applying $t$-test using Microsoft Excel ${ }^{\circledR}$. Data with $p$ values less than 0.05 was considered to be statistically significant.

\section{RESULTS AND DISCUSSION}

\section{Raag Ahir Bhairav}

Results regarding effect of sound-I are shown in Table 2. Growth and the particular test parameter(s) in case of all the test organisms experienced an enhancement under the influence of sound-I, except $S$. marcescens. The latter synthesized considerably lower pigment, when incubated in presence of music. This organism was earlier also found to experience a reduction in growth and prodigiosin production under influence of sound (raag Kirwani) corresponding to $38-689 \mathrm{~Hz}$ (Sarvaiya and Kothari, 2015). This range of frequency includes the one corresponding to sound-I used in this study, however relative proportion of different frequencies is likely to be different in different music patterns, and accordingly their effect and its magnitude may vary. During another study conducted by us (using sound corresponding to 41-645 Hz; data yet unpublished) $S$. marcescens was found to produce almost 1.5 times higher prodigiosin despite a small reduction in growth. Besides $S$. marcescens, two more gram-negative 
bacteria ( $X$. campestris and $C$. violaceum) were used in this study, and both were found to grow better under the influence of sound-I, with simultaneous enhancement in synthesis of their respective test metabolites. Both the pigment producing organisms used in this study were affected by sound stimulation, but their response was of opposite nature. Whereas $S$. marcescens responded to sound stimulation negatively, $C$. violaceum showed better growth and pigment (violacein) production in response to the same sound treatment. Production of both these pigments (prodigiosin and violacein) is known to be regulated by quorum-sensing in the producing bacteria (Wei et al., 2006; Zinger-Yosovich $\boldsymbol{e}$ al., 2006; Morohoshi et al., 2007). Magnitude of effect of sound stimulation on EPS production and prodigiosin synthesis respectively in $X$. campestris and $S$. marcescens was much higher than its effect on growth of these organisms, indicating that the cellular machinery related to growth was affected differently than that related to synthesis and/or secretion of EPS and prodigiosin

Table 2 Effect of raag Ahir bhairav on test organisms

\begin{tabular}{|c|c|c|c|c|c|c|c|c|c|}
\hline \multirow{3}{*}{$\begin{array}{l}\text { Organism } \\
\text { S. marcescens }\end{array}$} & \multicolumn{3}{|c|}{ Growth $\left(\mathrm{OD}_{660}\right)$} & \multicolumn{3}{|c|}{ Prodigiosin $\left(\mathrm{OD}_{535}\right)$} & \multicolumn{3}{|c|}{ Prodigiosin unit $\left(\mathrm{OD}_{535} / \mathrm{OD}_{660}\right)$} \\
\hline & $\begin{array}{c}\text { Control } \\
(\mathrm{Mean} \pm \mathrm{SD})\end{array}$ & $\begin{array}{c}\text { Experimental } \\
(\text { Mean } \pm \text { SD) }\end{array}$ & $\%$ change & $\begin{array}{c}\text { Control } \\
(\mathrm{Mean} \pm \mathrm{SD})\end{array}$ & $\begin{array}{c}\text { Experimental } \\
(\text { Mean } \pm \text { SD })\end{array}$ & $\begin{array}{c}\% \\
\text { Change }\end{array}$ & Control & Experimental & \%Change \\
\hline & $0.67 \pm 0.00$ & $0.64 \pm 0.00$ & $-4.32 * *$ & $0.52 \pm 0.03$ & $0.36 \pm 0.03$ & $-30.76^{* *}$ & 0.77 & 0.56 & -27.27 \\
\hline \multirow{3}{*}{ C. violaceum } & \multicolumn{3}{|c|}{ Growth $\left(\mathrm{OD}_{660}\right)$} & \multicolumn{3}{|c|}{ Violacein production $\left(\right.$ OD $\left._{585}\right)$} & \multicolumn{3}{|c|}{ Violacein unit $\left(\mathrm{OD}_{585} / \mathrm{OD}_{660}\right)$} \\
\hline & $\begin{array}{c}\text { Control } \\
(\text { Mean } \pm \text { SD })\end{array}$ & $\begin{array}{c}\text { Experimental } \\
(\text { Mean } \pm \text { SD) }\end{array}$ & $\%$ Change & $\begin{array}{c}\text { Control } \\
(\mathrm{Mean} \pm \mathrm{SD})\end{array}$ & $\begin{array}{c}\text { Experimental } \\
(\text { Mean } \pm \text { SD) }\end{array}$ & $\begin{array}{c}\% \\
\text { Change }\end{array}$ & Control & Experimental & $\%$ Change \\
\hline & $0.75 \pm 0.01$ & $0.78 \pm 0.01$ & $4.0^{*}$ & $0.37 \pm 0.01$ & $0.41 \pm 0.004$ & $10.81 *$ & 0.49 & 0.52 & 6.12 \\
\hline & \multicolumn{3}{|c|}{ Growth $\left(\mathrm{OD}_{660}\right)$} & \multicolumn{3}{|c|}{ EPS Production (g/L) } & \multicolumn{3}{|c|}{ EPS Production per unit OD (g/L) } \\
\hline \multirow{2}{*}{ X. campestris } & $\begin{array}{c}\text { Control } \\
(\text { Mean } \pm \text { SD) }\end{array}$ & $\begin{array}{c}\text { Experimental } \\
(\text { Mean } \pm \text { SD) }\end{array}$ & $\%$ Change & $\begin{array}{c}\text { Control } \\
(\text { Mean } \pm \text { SD) }\end{array}$ & $\begin{array}{c}\text { Experimental } \\
(\text { Mean } \pm \text { SD })\end{array}$ & $\begin{array}{c}\% \\
\text { Change }\end{array}$ & Control & Experimental & $\%$ Change \\
\hline & $0.45 \pm 0.01$ & $0.48 \pm 0.01$ & $6.66^{*}$ & $3.56 \pm 0.11$ & $4.70 \pm 0.20$ & $32.0 * *$ & 7.91 & 9.79 & 23.76 \\
\hline & \multicolumn{3}{|c|}{ Growth $\left(\mathrm{OD}_{660}\right)(1: 1$ dilution $)$} & \multicolumn{3}{|c|}{ Alcohol production (\% v/v) } & \multicolumn{3}{|c|}{ Alcohol production per unit OD (\% v/v) } \\
\hline \multirow{2}{*}{ S. cerevisiae } & $\begin{array}{c}\text { Control } \\
(\mathrm{Mean} \pm \mathrm{SD})\end{array}$ & $\begin{array}{c}\text { Experimental } \\
(\text { Mean } \pm \text { SD) }\end{array}$ & $\%$ Change & $\begin{array}{c}\text { Control } \\
(\mathrm{Mean} \pm \mathrm{SD})\end{array}$ & $\begin{array}{c}\text { Experimental } \\
(\text { Mean } \pm \text { SD })\end{array}$ & $\begin{array}{c}\% \\
\text { Change }\end{array}$ & Control & Experimental & $\%$ Change \\
\hline & $1.23 \pm 0.01$ & $1.34 \pm 0.01$ & $8.94 * *$ & $1.58 \pm 0.01$ & $1.74 \pm 0.00$ & $10.06^{*}$ & 1.29 & 1.30 & 0.77 \\
\hline \multirow{3}{*}{ L. plantarum } & \multicolumn{3}{|c|}{ Growth $\left(\mathrm{OD}_{660}\right)(1: 1$ dilution $)$} & \multicolumn{3}{|c|}{ pH } & & & \\
\hline & $\begin{array}{c}\text { Control } \\
(\text { Mean } \pm \text { SD) }\end{array}$ & $\begin{array}{c}\text { Experimental } \\
(\text { Mean } \pm \text { SD) }\end{array}$ & $\%$ Change & $\begin{array}{c}\text { Control } \\
(\text { Mean } \pm \text { SD) }\end{array}$ & $\begin{array}{c}\text { Experimental } \\
(\text { Mean } \pm \text { SD })\end{array}$ & $\begin{array}{c}\% \\
\text { Change }\end{array}$ & & & \\
\hline & $1.14 \pm 0.00$ & $1.21 \pm 0.00$ & $6.14 * *$ & $4.26 \pm 0.05$ & $4.03 \pm 0.05$ & $-5.39 * *$ & & & \\
\hline \multirow{3}{*}{ B. parabrevis } & \multicolumn{3}{|c|}{ Growth $\left(\mathrm{OD}_{660}\right)$} & \multicolumn{3}{|c|}{ IU } & & & \\
\hline & $\begin{array}{c}\text { Control } \\
(\text { Mean } \pm \text { SD) }\end{array}$ & $\begin{array}{c}\text { Experimental } \\
(\text { Mean } \pm \text { SD) }\end{array}$ & $\%$ Change & $\begin{array}{c}\text { Control } \\
(\text { Mean } \pm \text { SD) }\end{array}$ & $\begin{array}{c}\text { Experimental } \\
(\text { Mean } \pm \text { SD })\end{array}$ & $\begin{array}{c}\% \\
\text { Change }\end{array}$ & & & \\
\hline & $0.48 \pm 0.00$ & $0.57 \pm 0.02$ & $18.75^{* *}$ & $0.021 \pm 0.001$ & $0.026 \pm 0.001$ & $23.80 * *$ & & & \\
\hline
\end{tabular}

$* * p \leq 0.01, * p \leq 0.05$, '-'minus sign indicates a decrease over control

Both the gram-positive bacteria (B. parabrevis and L. plantarum) exhibited a higher growth in presence of music, with almost similar magnitude of change in their respective test parameters. A little higher $(5.39 \%)$ reduction in the $\mathrm{pH}$ of the growth medium of $L$. plantarum under the influence of sound may be owing to somewhat enhanced lactic acid production by this bacterium when induced by sound stimulation. Better growth of B. parabrevis under the influence of sound stimulation may be attributed to its higher $(23.80 \%)$ cellulase activity enabling it to utilize cellulose (the principal carbon source in the medium used) more effectively. S. cerevisiae also registered higher growth and alcohol production when subjected to sound stimulation. During our previous study (Sarvaiya and Kothari, 2015) we found membrane permeability of the test microorganisms to increase in response to sound stimulation. To investigate whether the altered growth of the test organisms exposed to sound treatment in this study is due to any change in movement of key molecules across the cell membrane, we measured the rate of glucose utilization by $S$. cerevisiae and $B$. parabrevis when incubated in presence of the test sound-I, by quantifying the extracellular glucose present in the growth medium at different time intervals. Sound stimulated culture of B. parabrevis was found to utilize glucose at a faster rate than control culture (Figure 3), and accordingly its growth was faster under the influence of sound. At the end of $24 \mathrm{~h}$ of incubation extracellular glucose concentration in the experimental tubes was $11.53 \%$ lesser than the control tubes and the corresponding increase in growth amounted to $15.94 \%$. Similarly, S. cerevisiae could also utilize glucose faster under the influence of sound. At the end of $48 \mathrm{~h}$ of incubation the extracellular glucose concentration in the experimental tubes was $17.39 \%$ lesser than that in control tubes, and the corresponding increase in growth and alcohol production was found to be $26.44 \%$ and $24.21 \%$ respectively (Figure 4).

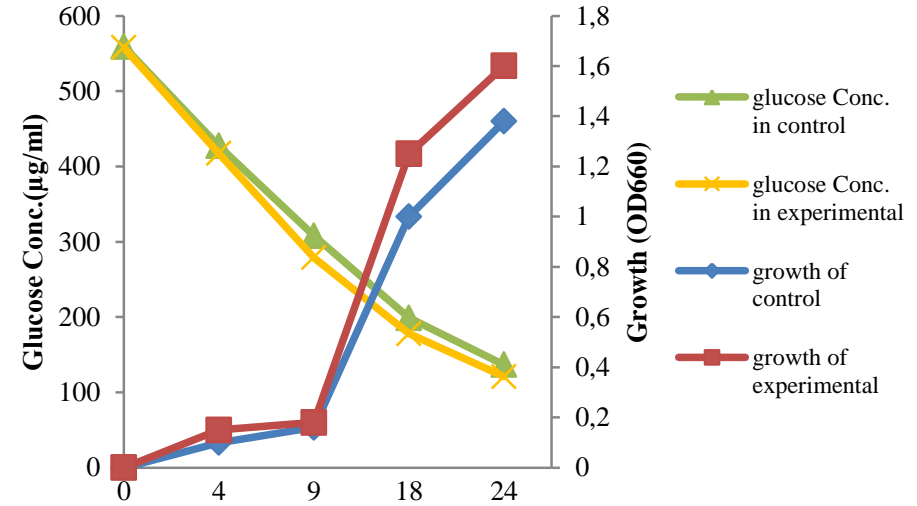

Time(h)

Figure 3 Faster glucose uptake by $B$. parabrevis under the influence of sound 

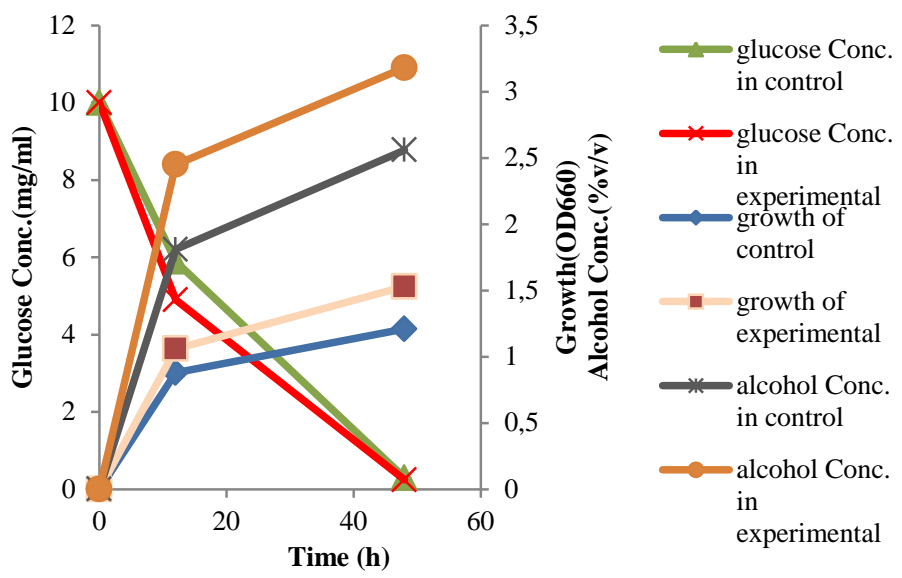

\section{Raag Piloo-Teentaal}

Results regarding the influence of sound-II on test organisms are presented in Table 3. S. marcescens suffered a marginal decrease in growth and a significantly heavy decrease in pigment (prodigiosin) production owing to sound treatment. Another pigmented organism, C. violaceum, used in this study also suffered a decrease in growth as well as pigment (violacein) production, when incubated in presence of sound. In contrast to both these pigmented gram-negative bacteria, the third pigmented gram-negative bacterium (X. campestris) used in this study exhibited higher growth and even higher EPS production under the influence of sound. C. violaceium responded differently to both the music patterns, positively to sound-I, and negatively to sound-II; whereas remaining two gram-negative bacteria employed in this study responded similarly to both the test music patterns.

Figure 4 Faster glucose uptake and better alcohol production by $S$. cerevisiae under the influence of sound

Table 3 Effect of raag Piloo on test organisms

\begin{tabular}{|c|c|c|c|c|c|c|c|c|c|}
\hline \multirow{3}{*}{$\begin{array}{l}\text { Organism } \\
\text { S. marcescens }\end{array}$} & \multicolumn{3}{|c|}{ Growth $\left(\mathrm{OD}_{660}\right)$} & \multicolumn{3}{|c|}{ Prodigiosin $\left(\mathrm{OD}_{535}\right)$} & \multicolumn{3}{|c|}{ Prodigiosin unit $\left(\mathrm{OD}_{535} / \mathrm{OD}_{660}\right)$} \\
\hline & $\begin{array}{c}\text { Control } \\
(\mathrm{Mean} \pm \mathrm{SD})\end{array}$ & $\begin{array}{c}\text { Experimental } \\
(\text { Mean } \pm \text { SD) }\end{array}$ & $\%$ change & $\begin{array}{c}\text { Control } \\
(\text { Mean } \pm \text { SD })\end{array}$ & $\begin{array}{c}\text { Experimental } \\
(\text { Mean } \pm \text { SD })\end{array}$ & $\begin{array}{c}\% \\
\text { Change }\end{array}$ & Control & Experimental & $\%$ Change \\
\hline & $0.67 \pm 0.001$ & $0.62 \pm 0.006$ & $-7.46 * *$ & $0.42 \pm 0.004$ & $0.16 \pm 0.007$ & $-61.9 * *$ & 0.62 & 0.25 & -59.67 \\
\hline \multirow{3}{*}{ C. violaceum } & \multicolumn{3}{|c|}{ Growth $\left(\mathrm{OD}_{660}\right)$} & \multicolumn{3}{|c|}{ Violacein production $\left(\mathrm{OD}_{585}\right)$} & \multicolumn{3}{|c|}{ Violacein unit $\left(\mathrm{OD}_{585} / \mathbf{O D}_{660}\right)$} \\
\hline & $\begin{array}{c}\text { Control } \\
(\mathrm{Mean} \pm \mathrm{SD})\end{array}$ & $\begin{array}{c}\text { Experimental } \\
(\text { Mean } \pm \text { SD) }\end{array}$ & $\%$ Change & $\begin{array}{c}\text { Control } \\
(\text { Mean } \pm \text { SD })\end{array}$ & $\begin{array}{c}\text { Experimental } \\
(\text { Mean } \pm \text { SD) }\end{array}$ & $\begin{array}{c}\% \\
\text { Change }\end{array}$ & Control & Experimental & $\%$ Change \\
\hline & $1.24 \pm 0.04$ & $0.94 \pm 0.01$ & $-24.19 * *$ & $1.29 \pm 0.10$ & $0.77 \pm 0.04$ & $-40.31^{*}$ & 1.04 & 0.81 & -22.11 \\
\hline & \multicolumn{3}{|c|}{ Growth $\left(\mathrm{OD}_{660}\right)$} & \multicolumn{3}{|c|}{ EPS Production (g/L) } & \multicolumn{3}{|c|}{ EPS Production per unit OD (g/L) } \\
\hline \multirow{2}{*}{ X. campestris } & $\begin{array}{c}\text { Control } \\
(\mathrm{Mean} \pm \mathrm{SD})\end{array}$ & $\begin{array}{c}\text { Experimental } \\
(\text { Mean } \pm \text { SD) }\end{array}$ & $\%$ Change & $\begin{array}{c}\text { Control } \\
(\mathrm{Mean} \pm \mathrm{SD})\end{array}$ & $\begin{array}{c}\text { Experimental } \\
(\text { Mean } \pm \text { SD })\end{array}$ & $\begin{array}{c}\% \\
\text { Change }\end{array}$ & Control & Experimental & $\%$ Change \\
\hline & $1.18 \pm 0.03$ & $1.29 \pm 0.03$ & $9.32 *$ & $3.73 \pm 0.05$ & $4.80 \pm 0.10$ & $28.68 * *$ & 3.16 & 3.72 & 17.72 \\
\hline & \multicolumn{3}{|c|}{ Growth $\left(\mathrm{OD}_{660}\right)$ (1:1 dilution) } & \multicolumn{3}{|c|}{ Alcohol production $(\% \mathrm{v} / \mathrm{v})$} & \multicolumn{3}{|c|}{ Alcohol production per unit OD (\% v/v) } \\
\hline \multirow{2}{*}{ S. cerevisiae } & $\begin{array}{c}\text { Control } \\
(\mathrm{Mean} \pm \mathrm{SD})\end{array}$ & $\begin{array}{c}\text { Experimental } \\
(\text { Mean } \pm \text { SD) }\end{array}$ & $\%$ Change & $\begin{array}{c}\text { Control } \\
(\mathrm{Mean} \pm \mathrm{SD})\end{array}$ & $\begin{array}{c}\text { Experimental } \\
(\mathrm{Mean} \pm \mathrm{SD})\end{array}$ & $\begin{array}{c}\% \\
\text { Change }\end{array}$ & Control & Experimental & $\%$ Change \\
\hline & $1.28 \pm 0.01$ & $1.34 \pm 0.0009$ & $4.68 *$ & $1.62 \pm 0.00$ & $1.82 \pm 0.04$ & $12.34 * *$ & 1.26 & 1.36 & 7.93 \\
\hline \multirow{3}{*}{ L. plantarum } & \multicolumn{3}{|c|}{ Growth $\left(\mathrm{OD}_{660}\right)(1: 1$ dilution $)$} & & pH & & & & \\
\hline & $\begin{array}{c}\text { Control } \\
(\mathrm{Mean} \pm \mathrm{SD})\end{array}$ & $\begin{array}{c}\text { Experimental } \\
(\text { Mean } \pm \text { SD) }\end{array}$ & $\%$ Change & $\begin{array}{c}\text { Control } \\
(\mathrm{Mean} \pm \mathrm{SD})\end{array}$ & $\begin{array}{c}\text { Experimental } \\
(\mathrm{Mean} \pm \mathrm{SD})\end{array}$ & $\begin{array}{c}\% \\
\text { Change }\end{array}$ & & & \\
\hline & $1.17 \pm 0.00$ & $1.21 \pm 0.01$ & $3.41 * *$ & $4.30 \pm 0.00$ & $4.16 \pm 0.05$ & $-3.25 *$ & & & \\
\hline \multirow{3}{*}{ B. parabrevis } & & rowth $\left(\mathrm{OD}_{660}\right)$ & & & IU & & & & \\
\hline & $\begin{array}{c}\text { Control } \\
(\mathrm{Mean} \pm \mathrm{SD})\end{array}$ & $\begin{array}{c}\text { Experimental } \\
(\text { Mean } \pm \text { SD) }\end{array}$ & $\%$ Change & $\begin{array}{c}\text { Control } \\
(\text { Mean } \pm \text { SD })\end{array}$ & $\begin{array}{c}\text { Experimental } \\
(\text { Mean } \pm \text { SD) }\end{array}$ & $\begin{array}{c}\% \\
\text { Change }\end{array}$ & & & \\
\hline & $0.50 \pm 0.03$ & $0.59 \pm 0.00$ & $18.0^{*}$ & $0.027 \pm 0.00$ & $0.032 \pm 0.00$ & $15.35 * *$ & & & \\
\hline
\end{tabular}

$* * p \leq 0.01, * p \leq 0.05$, "'minus sign indicates a decrease, when compared to control

Both the gram-positive test bacteria, B. parabrevis and L. plantarum grew better when subjected to sound treatment. The former could exhibit better cellulase activity in the sound stimulated condition, which might have allowed it to produce more biomass owing to better substrate (cellulose) utilization; or perhaps the higher cellulase activity might be simply resulting from increased cell number in the experimental tubes. The little $(3.25 \%)$ but significant reduction in $\mathrm{pH}$ of the growth medium brought by $L$. plantarum might have resulted from more lactic acid produced (owing to $3.41 \%$ higher cell mass) under the influence of sound. S. cerevisiae responded positively to both the sound patterns; however, alcohol production per unit of growth was higher in response to sound-II.

Growth rate and metabolism of $S$. cerevisiae growing in liquid culture has been shown through metabolomic study to get affected by sonic vibration (Aggio $\boldsymbol{e}$ al., 2012). Sonic frequencies employed in their work were $100 \mathrm{~Hz}$, and $1000 \mathrm{~Hz}$ in addition to broad-band music. They have reported a reduction in biomass production upto $14 \%$, when $S$. cerevisiae was grown in presence of music, with a simultaneous faster $(12.4 \%)$ growth rate. In the present study, we found the cell density of $S$. cerevisiae culture growing in presence of music to be higher than in absence of music (Table 2-3). When growth rate was calculated using the data from which graph shown in Figure 4 is plotted, it was found to be $23.82 \%$ higher $(P<0.01)$ in absence of music $\left(0.0403 \mathrm{~h}^{-1}\right)$ than that $\left(0.0307 \mathrm{~h}^{-1}\right)$ in its presence. In such another experiment performed with B. parabrevis, sound treatment was found to have a positive effect on cell density as well as growth rate (Figure 3).
Growth rate in presence of music $\left(0.212 \mathrm{~h}^{-1}\right)$ was $4.95 \%$ higher $(P<0.01)$ than that $\left(0.202 \mathrm{~h}^{-1}\right)$ in its absence.

This work involved investigation on effect of two different music patterns corresponding largely to the frequency ranges $172-581 \mathrm{~Hz}$ and $86-839 \mathrm{~Hz}$ on six different microorganisms. All the test organisms (except $S$. marcescens, and $C$. violaceum incubated with sound-II) grew better following incubation in presence of sound. Glucose uptake by B. parabrevis and $S$. cerevisiae was found to be faster under the influence of sound-I. Though few reports describing the effect of audible sound have accumulated in literature, this exciting topic warrants much more systematic studies, so that the molecular basis of microbial response to sound can be elucidated. Gu et al. (2013) reported sonic vibration $(5000 \mathrm{~Hz} ; 100 \mathrm{~dB})$ to promote growth of Escherichia coli, along with an increased total protein content and antioxidant enzyme activity. Ability of music to increase bacterial growth and substrate utilization was reported by Pornpongmetta and Thanuttamavong (2010). Ying et al. (2009) reported growth promoting effect of audible sound on E. coli.

Regarding the mechanism how audible sound affects the microbial growth and metabolism, not much can be commented with certainty. However, it may be postulated that sound waves while travelling through the liquid growth medium give rise to sonic vibrations, which may be sensed by the test microbial population through its mechanosensory receptors. Following this, the cell population may modulate its behavior in accordance to the magnitude and duration of the sonic vibration. Mechanosensitive ion channels are well 
characterized force-sensing systems in living organisms. Piezo channels can sense stress (sonic vibrations can be viewed as a type of stress posed to the microbial cells), and their gating can be regulated by mechanical force. Upon sensing the stress created by the sound waves, these mechanosensitive channels may signal the organism for generation of an appropriate physiological response (Martinac, 2012). Opening of such channels may be promoted by presence of membrane tension (Sawada et al., 2012), which in turn can affect movement of certain key ions across the cell membrane, ultimately resulting in an altered pattern of growth and metabolism. In bacteria, mechanosensitive channel proteins act as safety valves against osmotic shock, and in higher organisms they participate in sensing touch and sound waves (Ward et al., 2014). Once the biophysical mechanism regarding how force is sensed by mechanosensory channel protein and how the sensed force affects channel gating is completely understood, it will help to a good extent in explaining microbial response to sound stimuli. This is because through the process of mechnosensation, cells respond to variations in mechanical stress originating from sound or any such other environmental factor. Mechanosensitive channels are involved in regulation of the volume, morphology and migration of cells.

Different organisms may respond differently to a particular sound pattern because pressure distribution in the membrane varies with the type of membrane. The pressure profile of the membrane can be believed to be dependent on the intensity of the test sound, as well as, the inherent frequencies. A particular combination of a certain sound pattern and the test organism being studied will generate a particular pressure profile of the membrane, which is likely to affect the channel gating (Sawada et al., 2012).

\section{CONCLUSION}

This study demonstrates that microbial growth and metabolism do get affected when exposed to external audible sound. It is generally well accepted that sound (in form of music or otherwise) affects higher forms of life. Research regarding its effect on microbes is still in infancy. Questions like: Do microbes respond differently to different frequencies of audible sound; why the response of one organism to a particular sound pattern differs from that of another organism to same sound pattern; whether audible sound can affect quorum sensing in microbial populations significantly, and influence their behaviour, etc. remains to be explored. Further developments in the mechanosensory biology, along with transcriptome and/or metabolomic profiling of sound stimulated cultures can provide meaningful insights in the area of cell-sound interaction. Research in this area can open a new frontier for multidisciplinary work at the interfaces of microbiology, biophysics, and acoustics. Understanding the molecular basis of metabolic and physiological responses of sound stimulated microbial cells may enable effective manipulation of cell metabolism and proliferation in fermentors.

Acknowledgement: Authors thank Nirma Education and Research Foundation (NERF) for financial and infrastructural support; P N Gajjar and P D Lele (Gujarat University) for help with frequency analysis; Niral Sarvaiya, and Chinmayi Joshi for assistance in experimental set-up and manuscript formatting, respectively.

\section{REFERENCES}

AGGIO, R. B. M., OBOLONKIN, V., VILlAS-BÔAS, S. G. 2012. Sonic vibration affects the metabolism of yeast cells growing in liquid culture: a metabolomic study. Metabolomics, 8(4), 670-678. http://dx.doi.org/10.1007/s11306-011-0360-x

CHOO, J. H., RUKAYADI, Y., HWANG, J. K. 2006. Inhibition of bacterial quorum sensing by vanilla extract. Letters in Applied Microbiology, 42(6), 637 641. http://dx.doi.org/10.1111/j.1472-765x.2006.01928.x

GU, S. B., YANG, B., WU, Y., LI, S. C., LIU, W., DUAN, X. F., LI, M. W. 2013. Growth and physiological characteristics of E. coli in response to the exposure of sound field. Pakistan Journal of Biological Sciences: PJBS, 16(18), 969-975. http://dx.doi.org/10.3923/pjbs.2013.969.975

HASSANIEN, REDA H.E., TIAN-ZHENG HOU., AND BAO-MING LI. 2014. Effect of acoustic frequency technology on the growth of strawberry in solar greenhouse. 18th world congress of CIGR, Beijing. http://www.researchgate.net/publication/266383645

LI Y. X., YIN L. H., QI Y. 2012. Screening of Xanthomonas campestris

producing high viscosity and acid resistant xanthan gum and its fermentation process. Food Science, 33, 211-216.

MARTINAC, B. 2012. Mechanosensitive ion channels: an evolutionary and scientific tour de force in mechanobiology. Channels, 6(4), 211-213. http://dx.doi.org/10.4161/chan.22047

MATSUHASHI, M., PANKRUSHINA, A. N., TAKEUCHI, S., OHSHIMA, H., MIYOI, H., ENDOH, K., SAWADA, T. 1998. Production of sound waves by bacterial cells and the response of bacterial cells to sound. The Journal of General and Applied Microbiology, 44(1), 49-55. http://dx.doi.org/10.2323/jgam.44.49

MOROHOSHI, T., SHIONO, T., TAKIDOUCHI, K., KATO, M., KATO, N., KATO, J., IKEDA, T. 2007. Inhibition of quorum sensing in Serratia marcescens
AS-1 by synthetic analogs of N-acylhomoserine lactone. Applied and Environmental Microbiology, 73(20),

6339-6344.

http://dx.doi.org/10.1128/aem.00593-07

NIGAM, A., AYYAGARI, A. 2008. Lab manual in biochemistry, immunology, biotechnology, Tata-McGraw Hill, 193 p. ISBN 978-0-07-061767-4.

PORNPONGMETTA, S., THANUTTAMAVONG, M. 2010. Effects of music on microbial substrate utilization of aerobic bacteria from municipal wastewater treatment plant part II: comparative effects of musical characteristics, Journal of Research in Engineering and Technology 7(2):41-48.

PRADEEP, B. V., PRADEEP, F. S., ANGAYARKANNI, J., PALANISWAMY, M. 2013. Optimization and production of prodigiosin from Serratia marcescens MBB05 using various natural substrates. Asian Journal of Pharmaceutical \& Clinical Research, 6(1), 34-41.

SARVAIYA, N., KOTHARI, V. 2015. Effect of audible sound in form of music on microbial growth and production of certain important metabolites. Microbiology, 84(2), 227-235. http://dx.doi.org/10.1134/s0026261715020125

SAWADA, Y., MURASE, M., \& SOKABE, M. 2012. The gating mechanism of the bacterial mechanosensitive channel MscL revealed by molecular dynamics simulations: from tension sensing to channel opening. Channels, 6(4), 317-331. http://dx.doi.org/10.4161/chan.21895

WARD, R., PLIOTAS, C., BRANIGAN, E., HACKER, C., RASMUSSEN, A. HAGELUEKEN, G., SCHIEMANN, O. 2014. Probing the structure of the mechanosensitive channel of small conductance in lipid bilayers with pulsed electron-electron double resonance. Biophysical Journal, 106(4), 834-842. http://dx.doi.org/10.1016/j.bpj.2014.01.008

WEI, J. R., TSAI, Y. H., HORNG, Y. T., SOO, P. C., HSIEH, S. C., HSUEH, P. R., LAI, H. C. 2006. A mobile quorum-sensing system in Serratia marcescens. Journal of Bacteriology, 188(4),

$1518-1525$ http://dx.doi.org/10.1128/jb.188.4.1518-1525.2006

WILLIAMS, M. B. \& REESE, DARWIN. 1950. Colorimetric determination of ethyl alcohol, Analytical Chemistry., 22, 1556.

YING, J. C. L., DAYOU, J., PHIN, C. K. 2009. Experimental investigation on the effects of audible sound to the growth of Escherichia coli. Modern Applied Science, 3(3), 124. http://dx.doi.org/10.5539/mas.v3n3p124

ZINGER-YOSOVICH, K., SUDAKEVITZ, D., IMBERTY, A., GARBER, N C., GILBOA-GARBER, N. 2006. Production and properties of the native Chromobacterium violaceum fucose-binding lectin (CV-IIL) compared to homologous lectins of Pseudomonas aeruginosa (PA-IIL) and Ralstonia solanacearum (RS-IIL). Microbiology, 152(2), 457-463. http://dx.doi.org/10.1099/mic.0.28500-0 